\title{
Reading Biographies for Developing Narrative Self
}

\section{The Dalai Lama}

Patricia Cronin Marcello, 2012

Mumbai, India: Jaico Publishing House

192 pp., ISBN 13: 978-8184953589 (Paperback), \$8.99

Reviewed by

Sharmila Shyangtan* Kathmandu University School of Education, Lalitpur, Nepal

Biography is an important aspect of researching in education once one is planning for a narrative inquiry. Reading biography inspires me to think narratively. I am much interested in knowing and understanding the biography of the Dalai Lama not because of any religious footprints but because of his spiritual endeavours, which go beyond the humanist tradition of thinking. I have not canvassed any social research which questioned life before and after death. I do not have much interest in researching faithbased experience and the mystical experience of such a spiritual leader. I read a book from the sense of developing insights as a narrative inquirer.

The Dalai Lama is a biography written by Patricia Cronin Marcello which is published by Jaico Publishing House. The writer vividly described the Dalai Lama's childhood in Tibet, incarnation as the 14th Dalai Lama, and exile to India, finally, Tibet's struggle to regain independence from China. Additionally, she used a historical overview of the Tibetan crisis - a struggle to get freedom, and China's influence/invasion on Tibet and its consequences. More importantly, how the living

* Reviewer Email: sharmila.shyangtan@gmail.com https://orcid.org/0000-0002-2694-9682

\section{Journal homepages: ${ }^{1}$ http://www.kusoed.edu.np/journal/index.php/je \\ ${ }^{2}$ https://www.nepjol.info/index.php/JER/index}


God for Tibet and internationally respected human rights symbol, the Dalai Lama, dealt with the independence struggle and future of Tibet. The life journey of the Dalai Lama helped me to organize the events chronologically in time and space. I am much surprised to sense the timelessness and spacelessness while reading his biography as a narrative inquiry. How can social inquirers think of adopting such non-physical properties in the narrative inquiry? The form of narrative inquiry has been changing in the post-human research paradigm.

Chapter One and Two discuss the birth of the Tibet's Fourteenth Dalai Lama and search for the Fourteenth Ruler. He was born in North-eastern Tibet on July 6, 1935, as Lhamo Dhondup, which meant "wish-fulfilling goddess" to peasant parents. Usually, a child born was taken as another mouth to be fed. However, Lhamo Dhondup was considered special because when his father was bedridden to mysterious vertigo, after his birth, his father was out of the bed and cured miraculously. At that time, he was considered not an ordinary boy. I was not much surprised reading such a text, which might be fanatical for some Westerners, but I was brought up in the cultural setting where worshipping virgin girls as Kumari is an ancient Hindu practice. After they reach puberty, they become ordinary young women (Gellner, 2010), who is not only accepted but get involved in their everyday life rituals whereas to the people of Tibet, finding the Dalai Lama was not just finding the ruler but a living Buddha; a god-king was found, but a journey of hardship awaited before him. From these two chapters, I learned to adapt to the cultural belief system as a foundational base of narrative inquiry.

Chapter Three and Four discuss the journey of the Dalai Lama to his new destiny as a Fourteenth Dalai Lama and his life as a young pupil who was destined to show the path for Tibet. In other words, he becomes a supreme ruler of his country, where he defines all the control of the central region of Tibet with Lhasa as its capital. China and Tibet borders were not well-defined due to which Chinese Muslim warlord Ma Pu-Feng proclaimed himself a Chinese representative - a threat to people what if he uses the Dalai Lama for ransom and gain control over Tibet. Although a pillar outside Jokhang temple erected between 821 and 822, which speaks two countries as independent nations, where it was mentioned Tibetans are happy in the land of Tibet and Chinese in the land of China. However, more than for three hundred years, Tibet has been facing troubles as in 838, Ralpachen, the Third Religious King who was able to have diplomatic relations with China was assassinated, and Buddhism got opposed. So 
Buddhism flourished in Tibet after the 11th century, which was introduced by the Indian Scholar Atisha, who came to Tibet in 1042. Throughout time, Tibet had maintained its independence, although they use to pay taxes to Mongolia. After the Chinese nationalist drove the last Mongol emperor from China, Tibet was again without military protector but maintained the same relationship as with Mongolia.

Nevertheless, as The Art of War, a Chinese military treatise written by Sun Tzu originally in the 6th century $\mathrm{BC}$ reflects on Laying plan point number 18 as "All warfare is based on deception" (Tzu, 2011). It represents the Chinese movement, which deceived friends and foe, Tibet, with its independence through the skill of deception. This section gave me insights on presenting the emerging conflicts in the narrative inquiry in the broader social picture. The biography does not only tell stories of the celebrated individual but also sheds light on the particular social tension. Social tension in narrative inquiry emerged from the sociological imagination (Mills, 1959).

Chapters Five and Six discuss Tibet's struggle with China and difficult decisions the Dalai Lama had to make for the motherland Tibet. It is presented that in the Inter-Asia Relations conference convened in 1947 March in India, China rejected Tibetan independence, claiming it was still part of China. In contrast, Tibetans claimed that China was never a real ruler of Tibet. Additionally, an anthropologist and Tibetan historian explained the Simla agreement between China and Tibet stating that as per the Simla Convention, Tibet would be autonomous from China. China thus could maintain commissioner in Lhasa and an escort of up to three hundred men. China did not agree to the convention and representatives from China. The internal struggle and keeping up with the ongoing turmoil led the Dalai Lama to move to Southern Tibet for his protection. To the people of Tibet, Dalai Lama is Tibet, so when he escaped, he left two prime ministers in charge of the government of Lhasa. The signing of the SeventeenPoint Agreement shocked the Tibetan government as well as the Dalai Lama as he hoped the delegation in Beijing would bring good news.

Furthermore, his visit to China and the remark made by Mao made him construe Mao as the enemy of Buddhism and questioned Tibet's stability and trouble it will have to face. China continued to take the historical argument over Tibet's status very seriously (Sperling, 2009). Due to which they have not been able to find the middle path, which would be suitable for both the countries. 
Chapter Seven and Eight describe the relation among China (its vicious attack on people of Tibet), India (a newly independent country that tried to balance a wave of peace and harmony in the South-Asia region), and Tibet. This country is in the state of being swallowed by China. Tibet sovereignty depends on one person whom they called the living God, but he was in great concern as he did not want any bloodshed but wanted Tibet to be a sovereign country. He looked for guidance and assistance from India, but according to India, seventeen point Agreement reflected that Tibet became part of China and China had sovereignty over Tibet; India did not want to take Tibet's side against China. Even at this turmoil, he was successful in getting his doctorate in metaphysics, the Geshe degree, which is the highest academic degree awarded in Tibet. He hoped that by leaving Tibet, he would save thousands of lives. Moreover, eventually, situations arise so that he had to leave Tibet and be in exile. The year 2018 marks the 60th year of his seeking asylum in India (Tibet Journal, 2018). It appears the talk is not going anywhere as Chinese believe that Tibet is an integral part of China.

Chapters Nine and Ten discuss the Dalai Lama's attempts to gain independence of Tibet with the help of international support and applying the non-violence method. However, China, a country of communism, disregarded the world opinion and denounced the proposal put forward by the Dalai Lama. Dalai Lama, through writings as autobiography and other writings, gathers world attention, especially his world tour with a religious purpose, serves as attention grabber of the world. Nevertheless, independent Tibet and the road to a reconciliation was not viewed. He was strong despite having many personal losses and settling in India as an exile. He continued to fight for Tibet.

Chapter Eleven and Twelve present The Dalai Lama's recognition and Tibet's crisis bestowed upon the world where China refuses to accept the independence of Tibet as a separate country. The Dalai Lama became a celebrity and won many renowned awards for his non-violence and compassion for the people of the world. He hopes Tibet will regain autonomy and desires to return to Tibet as a private citizen. At this point, the question remains: will there be next to the Dalai Lama or not?

The writer has depicted the journey of the Dalai Lama from his birth, childhood, turmoil with China, exile, and life in exile - a journey which is not easy, but the Dalai Lama has dealt with compassion and reason. The Dalai Lama's efforts to gain 


\section{$122 \mid$ S. Shyangtan}

independence of Tibet have gone in vain. The Dalai Lama, while acknowledging their "human frustration" (Dalai Lama, 1996), cautions them against violence and advocates conflict resolution (as cited in Puri, 2002). He came under the influence of Mahatma Gandhi, following non-violence as his living principles (Thapa, 2014). It is remarkable how he has dealt with the issue with non-violence. I am touched by the words confided by the Dalai Lama "For the last thirty years, every day during my early morning meditations tears come to my eyes when I consider the innumerable suffering of sentient beings" (as cited in Ricard, 2011, p. 274).

Though the book targeted to the high school students, it is a source of inspiration in my personal life. Mostly I appreciate the way of crafting tales and giving sense to the events as a narrative inquirer. At the time of a humanist-dominated qualitative inquiry, reading the Dalai Lama implanted the seed of compassion, sympathy, coexistence as a post-humanist researcher. The book is simple in terms of its format and language, which might be the important qualities of any narrative researcher.

I experienced that reading biography helps to identify the narrative self of the researchers. Narratives occur with a premise of the individual concerning historical, social, and cultural context. Also, they help us understand and recognize that personal narratives are never simply "personal" (Kim, 2016, p. 126). The experience of the Dalai Lama is the construction of his interpretation of the social environment and his lived experience embedded with it. I recommend the book not only to those interested in knowing more about the life of the Dalai Lama, but also to all to understand or explore lived experience and perspective of the Dalai Lama of his everyday life, which includes his past, present, and future. It helps us make sense of the stories he tells as a qualitative researcher to look at how the story unfolds.

\section{References}

Gellner, D. (2010). Review of 'Living Goddess,' a film by Ishbel Whitaker. Himalaya, the Journal of the Association for Nepal and Himalayan Studies, 28(1), Article 9.

Retrieved from http:/digitalcommons.macalester.edu/himalaya/vol28/is s1/9 Kim, J. (2016). Understanding narrative inquiry. Thousand Oaks, CA: Sage. Mills, C. W. (1959). The sociological imagination. Oxford, England: Oxford University Press. 
Reading Biographies for Developing Narrative Self | 123

Puri, B. (2002, Aug 24-30). Deconstructing the Dalai Lama on Tibet. Journal of Economic and Political Weekly, 37(34), 3500-3503.

Ricard, M. (2011). The Dalai Lama: Happiness from within. International Journal of Wellbeing, 1(2), 274- 290. https://doi.org/10.5502/ijw.v1 i2.9

Sperling, E. (2009). Tibet and China: The interpretation of history since 1950.

Retrieved from https://chinaperspectives.revues.org/4839

Thapa, S. P. (2014). Struggle of Tibet: From armed conflict to non-violence (Master's thesis). Norwegian University of Life Sciences, Oslo, Norway. Retrieved from https:/hdl.handle.net/11250/225277

Tibetan Journal. (2018). India, China must talk to resolve Tibet issue. Retrieved from http//www.tibetanjournal.com/india-china- must-talk-to-resolve-tibet-issue/

Tzu, S. (2011). The art of war (J. Trapp, Trans.). London, England: Amber Books.

\section{To cite this article:}

Shyangtan, S. (2019). Book review: Reading biographies for developing narrative self. Journal of Education and Research, 9(1), 118-123. https://doi.org/10.3126/ier.v9i1.28828 